\title{
IMPROVEMENT OF TOURIST VALORIZATION - CASE STUDY OF THE VIMINACIUM ARCHAEOLOGICAL SITE
}

\author{
Sanja Pavlović ${ }^{* 1}$ \\ "University of Belgrade - Faculty of Geography, Belgrade
}

\begin{abstract}
As an integral part of tourist-geographical research of values, tourist valorization is considered complementary to various spatial, economic, ecological and social aspects. The paper discusses the possibilities and limitations of improving the tourist valorization of the Viminacium Archaeological Site, using the existing research and literature, as well as the field work of the author, and also two complex models of valorization have been presented. The results of the research show that numerous indicators applied in different models help complex view of the archaeological site and environment, and that they are in accordance with modern trends in scientific research, which significantly contributes to the improvement of evaluation of Viminacium for the purpose of tourism.
\end{abstract}

Key words: tourism, evaluation, models, Viminacium.

\section{Introduction}

Tourist valorization as a qualitative and quantitative assessment of the tourist value is a significant stage in tourism planning, and at the same time very complex, especially in the part relating to the evaluation of both the motive and the constituent elements of tourism potential. Estimating the elements value of the tourism potential helps in determining the usable

${ }^{1}$ Corresponding author: S. Pavlović, University of Belgrade - Faculty of Geography, Studentski trg 3/III, 11,000 Belgrade, Serbia; e-mail: spavlovic20@gmail.com 
and traffic value. The aim of the paper is to determine the current level and models of the tourist valorization of the Viminacium Archaeological Site, to identify new measures for improving the evaluation as per the concept of sustainable development, in accordance with research trends. There are two hypotheses in this paper. One is that the concept of tourist valorization implies the continuous introduction of new indicators (elements, criteria) and models. The second hypothesis should prove or deny a significant impact of the time dimension of tourist valorization on its complexity.

Table 1 - Tourist valorization of Viminacium according to the Hilary du Cros model

\begin{tabular}{|c|c|c|}
\hline SUBINDICATORS & HIGHER GRADES & LOWER GRADES \\
\hline market attractiveness & $\begin{array}{l}\text { cultural good is associated } \\
\text { with culture and an } \\
\text { interesting story can be } \\
\text { told, tourist activity in the } \\
\text { region and attractiveness for } \\
\text { special needs }\end{array}$ & $\begin{array}{l}\text { complementarity with } \\
\text { other tourist products at } \\
\text { the destination, familiarity } \\
\text { outside the local area }\end{array}$ \\
\hline $\begin{array}{l}\text { factors important in } \\
\text { designing a tourist } \\
\text { product }\end{array}$ & service conveniences & $\begin{array}{l}\text { access to cultural good, } \\
\text { transport from the emission } \\
\text { centre to the cultural good, } \\
\text { proximity to other attractions }\end{array}$ \\
\hline cultural significance & representativity & $\begin{array}{l}\text { historical value, aesthetic } \\
\text { value, social value and rarity } \\
\text { of the cultural good }\end{array}$ \\
\hline robustness & $\begin{array}{l}\text { management plan, } \\
\text { monitoring and } \\
\text { maintenance of investment } \\
\text { potential, negative impacts } \\
\text { of visitors on the local } \\
\text { community and possibility } \\
\text { that the modification has a } \\
\text { negative impact on the local } \\
\text { community }\end{array}$ & $\begin{array}{l}\text { possibility that the } \\
\text { modification has a negative } \\
\text { impact on the physical } \\
\text { condition of the cultural } \\
\text { good and negative effects of } \\
\text { the visitors on the physical } \\
\text { condition of the cultural } \\
\text { good }\end{array}$ \\
\hline
\end{tabular}

Source: Марковић \& Петровић, 2012. 
It is clear that no model can provide the best forecasts for the destination at the short, medium and long term (Hassani, Sirimal Silva, Antonakakis, Filis \& Gupta, 2017). Scientifically recognized and recognizable model of tourist valorization of cultural goods is the Hilary du Cros model (du Cros, 2000). On the example of the Viminacium Archaeological Site, this model was applied by Маровић and Петровић (2012) and was repeatedly applied in the valorization of the monumental heritage in our country (Stamenković \& Jakšić, 2013; Boškov, Kortla, Košić \& Lulić 2015; Voza \& Vuković, 2012; Bjeljac, Terzić \& Ćurčić, 2014).

Tourist valorization according to the CREM model was developed by Božić \& Tomić (2016), Tomić \& Božić (2014), and Божић (2016) applied it in the doctoral thesis on the example of the cultural route The Way of the Roman Emperors, to which the Viminacium Archaeological Site belonged to. The model consists of two basic groups of indicators: basic values of the cultural route and values specific to tourism.

Table 2 - CREM model of the tourist valorization

\begin{tabular}{|c|c|}
\hline BASIC VALUES & VALUES SPECIFIC TO TOURISM \\
\hline $\begin{array}{l}\text { scientific values: cultural, historical, artistic, } \\
\text { social, educational, research and aesthetic }\end{array}$ & \multirow{2}{*}{$\begin{array}{l}\text { functional values: tourist- } \\
\text { geographical location of the route, } \\
\text { signaling and concentration of } \\
\text { attractions on the route }\end{array}$} \\
\hline \multirow{2}{*}{$\begin{array}{l}\text { route-specific values: uniqueness and } \\
\text { rarity in the region, geographical character, } \\
\text { number of attractive sites, attractiveness of } \\
\text { the theme promoted by the route, existence } \\
\text { of the organization that manages the route, } \\
\text { existence of the route management plan }\end{array}$} & \\
\hline & \multirow{3}{*}{$\begin{array}{l}\text { additional values: promotion, } \\
\text { accommodation, restorative } \\
\text { services, existence of a tourist } \\
\text { guide service, infrastructure, } \\
\text { interpretation, event organization, } \\
\text { animation, authentic experience, } \\
\text { attractiveness of the sites on the } \\
\text { route, additional interpretative } \\
\text { possibilities, tourist arrangements, } \\
\text { level of visit, souvenirs }\end{array}$} \\
\hline $\begin{array}{l}\text { economic importance of the route: } \\
\text { contribution to the local community, impact } \\
\text { on the economic development of the region } \\
\text { or the country as a whole, potential for } \\
\text { investing, creation of a brand, creation of a } \\
\text { positive image of the country, possibilities } \\
\text { for cross-border cooperation }\end{array}$ & \\
\hline $\begin{array}{l}\text { protection and conservation: current state } \\
\text { of the site on the route, vulnerability / } \\
\text { sensitivity of the site, level of protection, } \\
\text { number of tourists }\end{array}$ & \\
\hline
\end{tabular}

Source: Božić \&Tomić, 2016. 
Such models of valorization are very detailed, systematic and encompass numerous criteria necessary in the tourist evaluation of the monumental heritage. As a problem in tourist valorization, subjectivity is imposed in the evaluation of individual indicators, especially those that cannot be quantified (e.g., the attractiveness of the topic promoted by the route, the possibility of an interesting visit), and it is clear that the culture valorization is also influenced by the cultural background of a potential tourist. Numerical, descriptive and graphic expression help researchers to present the views of tourist experts or tourists, and by comparing different estimates of tourist values by relevant groups, it is possible to determine the overall importance of tourist values. Relation to culture and its valorization are, according to classical theories, strongly influenced by social stratification (Marina, 2015). Nevertheless, tourist valorization is distinguished as a useful approach for different target groups, and also the role of tourists in developing destinations (Frenzel, 2017).

\section{Methodology}

Exploratory (reconnoitre) and descriptive (illustrative) research were used in this paper. Primary data were collected by field research, i.e., observation. Exploratory research is based on literature, i.e., secondary data, experiences and analysis of the selected case. Qualitative research is based on the contextual dimension of data, empirical observations and observation of participants in tourism trends. Given that there are no exact methods for quantifying the value of tourism resources, in practice, the assessment is left to the intersubjective agreement of the participants in the assessment. The applied scales do not have fixed and universal values, but are determined according to specific needs. In this paper, the qualitative research was applied and not the quantitative one.

In the preparation and analytical-synthetic procedures in the final part of the field research, the consideration of the historical and geographical development of the tourist valorized destination appears, taking into account the spatial-temporal complexity and the gradual development of tourism in the observed geographical area, as an essential condition for the development of future models of tourist valorization (Vojnović, 2016). In recent literature, time complexity points to tensions between the valorization of the past and future development, as well as the shift from traditional preservation of sites to future-oriented contents, on the one hand, while operational needs and normative principles of quality are on the other (Ducros, 2017). 
In the process of valorization, it should be taken into account that the values of the heritage are contingent, not objectively given, and not fixed, but are changed depending on the context of heritage as a tourist value (Alazaizeh, Hallo, Backman, Norman \& Vogel, 2016).

The complexity of the study and evaluation of areas includes a number of elements, such as the involvement of local communities, education and training, authenticity and interpretation, tourism management in the context of sustainability, integrated planning, management and involvement of interested parties, market and product diversification, adequate funding, support systems and international management (Loulanese, T. \& Loulanski, V., 2011), as wel as how tourism attractions affect the development of tourism within the destination (Truchet, Piguet, Aubert \& Callois, 2016). Approaches to planning tourism research show that traditional approaches are still relevant, but there is a need to recognize different contextual and historical dimensions in diverse research aspects. These historical and contextual elements affect current and future characteristics and relations of power in tourism and can help to understand how tourism functions with sites and sites with tourism (Saarinen, Rogerson \& Hall, 2017).

\section{Results and discussion}

The villages of Kostolac and Drmno, $13 \mathrm{~km}$ from Požarevac, are located on the remains of the ancient city of Viminacium, once the capital of the Roman province of Upper Moesia, and in the late antique of the Moesia I. The VII Claudius Legion was situated there. The wider urban territory covered an area of 450 ha, and the narrower urban territory of 220 ha. The city was the episcopal seat in the 4th century, and it was destroyed by the Huns in the middle of the 5th century. As a military base, it was restored under the Emperor Justinian. More than 14,000 graves with numerous attachments were found, including the mausoleum of the Emperor Hostilian in the central part. The site was protected in 1949, and classified as a cultural good of exceptional importance in 1979. Since 2009, the boundaries and regimes of protection have been defined (Nikolić, Ilić \& Rogić, 2013).

Construction of the visitor centres at archaeological sites is one of the most effective ways of presenting heritage. Special attention has been given to the northern gate of the military camp, parts of the discovered termi and mausoleum with burial places after the year of 2000, where the structures with laminated wood construction were built for the purpose of protec- 
tion and presentation, (Nikolić, 2011). For the first time in Viminacium, we have started applying new forms of sites interpretation, which are based on creative and interactive experiences and visitor experiences (Maksin, Pucar, Korać and Milijić, 2013). Since its opening in 2006, the Viminacium Archaeological Park has been the destination of domestic and foreign visitors.

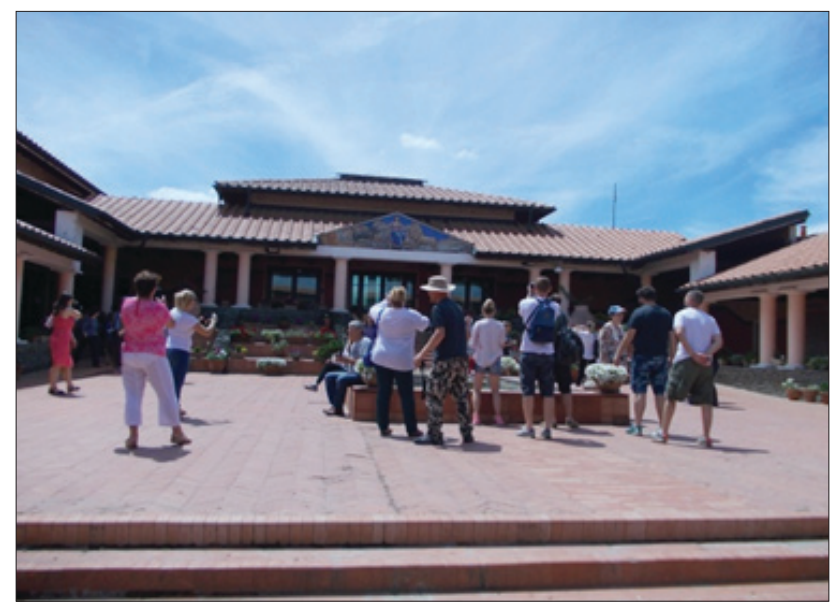

Figure 1 - Roman villa in Viminacium as a multifunctional space

The construction of the scientific and research centre of the Viminacium Archaeological Park has created a unique location for the stay of researchers, scientists and tourists. Covered and open to the visitors are the following sites: Mausoleum where the Roman Emperor Hostilian was buried, the northern gate of the military camp originated from the 1st century, the Roman thermal spa from the 1st century, the mammoth skeleton excavated in 2009 and the scientific-research centre of multiple purposes. Scientists and professors can use cabinets, library and atrium for research, work with students, summer schools, scientific meetings. The building was designed in the form of a Roman villa of two levels. In the upper level, there is a working and accommodation space, and in the lower (underground): museum, depots and hall. Infrastructure facilities include a souvenir shop, a tavern for relaxation and refreshment of visitors.

The reconstruction of the aqueduct and the watercourse has been planned (the works should be completed in 2018), and the amphitheater will be a stage for music and drama festivities. Investment projects include the 
construction of hippodromes, which will be used to maintain horse races, races and Roman chariot racing, digging the canals from the Danube to the site (in order to be more accessible to ships) and horticultural arrangement. The realization of investment plans has been delayed, and the deadlines set for the commencement of works have been moved about four years in advance, except for an amphitheater. The conditions for research and presentation of ancient remains are numerous (Golubović, Korać \& Milovanović, 2010), especially considering that only $2 \%$ of the archaeological site has been explored. Rescue interventions of the original archeological area reveal the social-cultural and historical value inherent in it (Holtorf \& Kristensen, 2015).

As the Viminacium Archaeological Park is part of the project The Roads of the Roman Emperors, the employment of local people has been planned, engaged as guides and in activities that provide support and supply of facilities on the route (catering, souvenir production). It is necessary to organize education programmes that would help members of the local community in the performance of tourism services. Community-based tourism can better encourage generative, not just sustainable forms of empowering the destination (Knight \& Cottrell, 2016).

The promotion of the site is achieved by reviving the way of life during the time of the Romans (feasts, legionary parades, chariot racing, comedy and drama festivals), but these activities should be more frequent. The research conducted by Taketo, Takanobu, Shoji \& Takayuki (2011) showed that tourists conveniently evaluated old items in a historical heritage destination. The essence of the model for the development of the archaeological site is that it becomes a tourist attraction by protection and revival. The site is protected by organization from robbers and illegal construction, and at the same time the awareness of the local population about the value of cultural heritage is raised.

The Archaeological Park Viminacium is an example of an economically sustainable model in the function of regional development, promoted at tourist fairs in Milan, Berlin, London, Cologne. A sustainable presentation is organized so that regardless of the increased number of tourists, especially in the period May-October, the carrying capacity of the archaeological site can be controlled. The maximum number of visitors is around 200 per day, estimated on the basis of the number of scheduled daily trips (four). After the establishment of the archaeological park, in 2007, Viminacium was visited by more than 50,000 visitors, and, 55,000 visitors in 2008, among which there were 10,000 foreigners. Visits of archaeologists and tourists from Switzerland, France, USA, the Netherlands, Iceland, Austria, Germany, Australia ... were recorded (Maksin et al., 
2013). In the two spring months of 2017 , about 50,000 visitors were registered, which was at the annual level from ten years ago, taking into account that the number of foreign visitors coming by ships was smaller.

One of the main problems is the lack of trained guides, with sufficient knowledge of ancient history and archeology, which according to European standards is a priority. Another problem is the proximity of the Kostolac B thermal power plant and the Drmno land mine, which endanger the location from the south and the southeast, and the the third problem represent bad local roads leading to the archaeological park. Some parts of the wider area of the archaeological site, such as aqueduct, late antique basilicas, rustic villas and roads, are particularly vulnerable. The source of pollution of the environment is the ash dumping site of the thermal power plant. The local people found ceramics, money and jewelry in the fields and sold them to antique dealers and collectors, so a significant number of artifacts was located abroad. Since most of the sites are agricultural land owned by the local people, the land should be purchased or cultivated areas should be offered in other locations (Mrđić, Raičković \& Redžić, 2010).

The Organization for the Black Sea Economic Cooperation has accepted two regional cultural tourism projects, which include Viminacium: The Roads of the Roman Emperors and Cultural Water Corridors (Maksin et al., 2013). Viminacium is the leading site in the project The Roads of the Roman Emperors, realized by the Archaeological Institute from Belgrade, the Ministry of Education, Science and Technological Development, the Ministry of Culture and the Tourist Organization of Serbia. The T-PAS project includes the tourist promotion of archaeological sites along the Aquileia-Viminacium route, and is co-financed by the European Union. The aim of the project is to promote the ancient Roman road that was being used to connect the cities of Aquileia and Viminacium via the Emona (present-day Ljubljana) in a cultural and tourist manner (http://viminacium.org.rs/projekti/t-pas/). One group of activities of the Arkwork project (involving partners from twenty-three European countries) deals with the integration and improvement of the accommodation and use of museum collections, as well as the ways of presenting archaeological sites, among which is Viminacium (http://viminacium.org. rs/projekti/projekat -arkwork). The Viminacium Archaeological Park has been included in the European cycling route 6 (Atlantic - Black Sea).

Integral planning is of particular importance in the process of tourist valorization (Јоцић, 2013), which contributes not only to the development of tourism, but also to the social and economic effects of the domicile population 
(Stankovic, 2016). Improving the evaluation of the Viminacium Archaeological Site can contribute to the realization of general and operational goals of tourism development: sustainable development of tourism, with more efficient implementation of international standards, year-long offer with the integration of the offer of the "Danube Ecological Zone", partnership of private, public and non-governmental sectors, efficient organization of stakeholders (including local population), inter-municipal and regional cooperation, activation of tourism potentials in line with demand trends, market standards and socio-economic interests of the local community, promotion of settlements in the coastal area and touristic motifs in the hinterland of the Danube in terms of their opening towards the river and the tourist market of Europe (Просторни план подручја посебне намене археолошког налазишта Виминацијум, 2012). Inclusion of different stakeholders in tourism management and understanding of their value orientation are key to achieving tourism sustainability (Alazaizeh et al., 2016). Marketing recommendations to the location manager should be based on research that, inter alia, relates to different segments and target groups of visitors (Petr, 2015). The importance of the perception of the young local population in achieving sustainable tourism development and the planning of local promotion programmes should be also noted (Jaafar, Md Noor \& Rasoolimanesh, 2015).

In order to improve the tourism development in the Viminacium Archaeological Site, a Corporate Social Responsibility (CSR) survey, which so far has been focused on the micro level, could be done. Consolidation model of socially responsible business can be applied on the basis of employee attitudes, but also from the viewpoint of visitors (Wells, Smith, Taheri, Manicka \& McCowlen, 2016).

The intangible archaeological heritage, as a knowledge that arises from the interpretation at archaeological sites, should be also taken into consideration. Archaeological heritage is often equated with tangibility, which results in the omission of experiences that the intangible archaeological heritage can offer (Ross, Saxena, Correia \& Deutz, 2017). Archaeological sites attract the interest of tourists due to striking stories and creativity in providing tourist services. In this respect, the archaeological framework for tourism can be revised and the different dimensions of heritage and the ways in which it can be presented (Willems \& Dunning, 2015) can be considered. In the context of archaeological tourism, the perspective implies the active participation of tourists, providers and archeologists in the process of interpreting and perceiving the past (Minkiewicz, Evans \& Bridson, 2014). This means the participation of guides who provide anecdotal evidence with scriptwriting and tutorials about the location in order to revitalize it, operators offering a cultural tourism season, managers 
who oversee interpretation and marketing heritage (Mortensen, 2014).

\section{Conclusion}

Field research, relevant information, literature, visual perception and observation show what are the possibilities and limitations in terms of improving the tourist valorization of the Viminacium Archaeological Site. The organization of the World Congress of Archeologists in Viminacium, announced for 2018, provides the opportunity to promote the site internationally. For this purpose, accommodation facilities will be built, similar to those where military legionaries used to stay. After a large financial investment in the site, the tourist offer has been modernized and raised to an enviable level, with relatively high ticket prices and services. Tourism use of the area is expected to achieve positive economic effects, increase the employment of the local population and improve the image of the destination. Research, conservation and protection should be carried out in parallel with tourist use, as tourist valorization implies the provision of additional financial resources.

The first hypothesis set in the paper has been justified because tourist valorization has an interdisciplinary character, with numerous possibilities of introducing new indicators and supplementing existing models or, possibly, forming new ones. In this context, international standards for the organization, management and use of localities, stakeholder relations and attitudes of different target groups should be followed, as confirmed by the results of this paper. Valorization was realized in the function of the needs of certain groups of tourists (market segments), as well as the activities they dealt with. The second hypothesis has been also confirmed, because according to the Hilari du Cros model applied by Марковић and Петровић (2012) on the example of Viminacium, a higher rating was given to the negative impact of visitors on the local community and the possibility that the modification had a negative impact on the local community. The current state of the site does not support this conclusion, since it is obvious that there have been tendencies of involving the local population in activities at the site in the last five years.

\section{Acknowledgements}

The paper is the result of the research within the project no. 176008 funded by the Ministry of Education and Science of the Republic of Serbia. 
Improvement of Tourist Valorization - Case Study of the Viminacium Archaeological Site

\section{References}

Alazaizeh, M., Hallo, J., Backman, S., Norman, W., \& Vogel, M. (2016). Value orientations and heritage tourism management at Petra Archaeological Park, Jordan. Tourism Management, 57, 149-158.

Bjeljac, Ž., Terzić, A., \& Ćurčić, N. (2014). Tourismological valorization of intangible cultural heritage of Serbia According to the Hilary du Cros method. Issues in Ethnology Anthropology, 9(1), 195-217.

Boškov, J., Kortla, S., Košić, K., \& Lulić, D. (2015). Tourist Valorization of the Mileševa Monastery (Serbia). European Researcher, 98(9), 578-589.

Božić, S., \& Tomić, N. (2016). Developing the Cultural Route Evaluation Model (CREM) and its application on the Trail of Roman Emperors, Serbia. Tourism Management Perspectives, 17, 26-35.

Du Cros, H. (2000). Planning for Sustainable Cultural Heritage Tourism in Hong Kong. Paper presented at Lord Wilson Heritage Trust Council, SAR.

Ducros, H. (2017). Confronting sustainable development in two rural heritage valorisation models. Journal of Sustainable Tourism, 25(3), 327-343.

Frenzel, F. (2017). Tourist agency as valorisation: Making Dharavi into a tourist attraction. Annals of Tourism Research, 66, 159-169.

Golubović, S., Korać, M., \& Milovanović, B. (2010). Arheološki parkViminacijum - turistička atrakcija. U P. Petrović i V. Golubović (ur.), Unapređenje turizma kao faktor razvoja privrede Republike Srbije (423-430). Beograd: Institut za međunarodnu politiku i privredu.

Hassani, H., Sirimal Silva,. E., Antonakakis, N., Filis. G., \& Gupta, R. (2017). Forecasting accuracy evaluation of tourist arrivals. Annals of Tourism Research, 63, 112-127.

Holtorf, C., \& Kristensen, T.M. (2015). Heritage erasure: Rethinking 'protection' and 'preservation'. International Journal of Heritage Studies, 21(4), 313-317.

Jaafar, M., Md Noor, S., \& Rasoolimanesh, M. (2015). Perception of young local residents toward sustainable conservation programmes: A case study of the Lenggong World Cultural Heritage Site. Tourism Management, 48, 154-163.

Knight, D., \& Cottrell., P. (2016). Evaluating tourism-linked empowerment in Cuzco, Peru. Annals of Tourism Research, 56, 32-47. 
Loulanski, T., \& Loulanski, V. (2011). The sustainable integration of cultural heritage and tourism: a meta-study. Journal of Sustainable Tourism, 19(7), 837-862.

Maksin, M., Pucar, M., Korać, M., \& Milijić, S. (2013). Menadžment prirodnih $i$ kulturnih resursa u turizmu. Beograd: Univerzitet Singidunum - Fakultet za turistički i hotelijerski menadžment.

Marina, L. (2015). Cultural participation and touristic valorization of the local cultural heritage. Annales Universitatis Apulensis Series Oeconomica,17(2), 54-65.

Minkiewicz, J., Evans, J., \& Bridson, K. (2014). How do consumers co-create their experiences? An exploration in the heritage sector. Journal of Marketing Management, 30(1-2), 30-59.

Mortensen, L. (2014). Branding Copan: Valuing cultural distinction in an archaeological tourism destination. Journal of Tourism and Cultural Change, 12(3), 237-252.

Mrđić, N., Raičković, A., \& Redžić, S. (2010). Itinerarium Romanum Serbiae - putevima rimskih imperatora po Srbiji. Kulturno nasleđe u službi turizma i održivog razvoja. U Petrović, P. i Golubović, V. (ur.), Unapređenje turizma kao faktor razvoja privrede Republike Srbije, (444-454). Beograd: Institut za međunarodnu politiku i privredu.

Nikolić, M. (2011). Vizitorski centri na arheološkim lokalitetima u Srbiji kao podsticaj ekonomskom razvoju zemlje. Istraživanja i projektovanja za privredu, 9(1), 253-258.

Nikolić, E., Ilić, O., \& Rogić, D. (2013). Possibilities of Defining the Archaeological Site of Viminacium as a Unique Cultural Landscape. In A. Filipović, and W. Troiano (Eds.), Strategie e Programmazione della Conservazione e Trasmissibilità del Patrimonio Culturale [Strategies and Planning of Conservation and Transmissibility of Cultural Heritage], (pp. 260-271). Rome: Edizioni Scientifiche Fidei Signa.

Petr, C. (2015). How heritage site tourists may become monument visitors. Tourism Management, 51, 247-262.

Ross, D., Saxena, G., Correia, F., \& Deutz, P. (2017). Archaeological tourism: A creative approach. Annals of Tourism Research, 67, 37-47.

Saarinen, J., Rogerson, C., \& Hall, C.M. (2017). Geographies of tourism development and planning. Tourism Geographies, 19(3), 307-317.

Stamenković, I., \& Jakšić, S. (2013). Tourism potential valorisation of the old town centre in sombor based on the Hilary du Cros model. European Researcher, 6-2(53), 1746-1754. 
Stanković, S. M. (2016). Theoretical foundations of tourist valorisation. Zbornik radova - Geografski fakultet Univerziteta u Beogradu, 64, 5-46.

Taketo, N., Takanobu, Y., Shoji, I., \& Takayuki, K. (2011). Applying the caption evaluation method to studies of visitors' evaluation of historical districts. Tourism Management, 32(5), 1061-1074.

Tomić, N., \& Božić, S. (2014). A modified geosite assessment model (MGAM) and its application on the Lazar Canyon area (Serbia). International Journal of Environmental Research, 8(4), 1041-1052.

Truchet, S., Piguet, V., Aubert, F., \& Callois, J.M. (2016). Spatial influence of attractions on tourism development. Tourism Geographies, 18(5), 539-560.

Vojnović, N. (2016). Terenska istraživanja u metodološkom sustavu turističke geografije. Hrvatski geografski glasnik, 78(1), 97-123.

Voza, D., \& Vuković, M. (2012). Tourist attractiveness of Felix Romuliana archaeological site. Glasnik Srpskog geografskog društva, 92(3), 157-182.

Wells, V., Smith, D., Taheri, B., Manika, D., \& McCowlen, C. (2016). An exploration of CSR development in heritage tourism. Annals of Tourism Research, 58, 1-17.

Willems, A., \& Dunning, C. (2015). Solving the puzzle: The characteristics of archaeological tourism. In M. van der Dries, S. van der Linde, A. Strecker (Eds.), Fernweh: Crossing borders and connecting people in archaeological heritage management (68-71). Leiden: Sitestone Press.

Божић, С. (2016). Утицај личности туристе на бренд дестинације и туристичко понашање на примеру локалитета културне руте. (Необјављена докторска дисертација). Универзитет у Новом Саду, Природно-математички факултет, Департман за географију, туризам и хотелијерство, Нови Сад.

Јоцић, Н. (2013). Туристичка валоризација модерне архитектуре Новог Београда. Зборник радова Географркког факултета Универзитета у Београдy, 61, 179-192.

Марковић, J., и Петровић, М. (2012). Туристичка валоризација археолошког налазишта Виминацијум према моделу Хилари ду Крос. Зборник радова Департмана за географију, туризам и хотелијерство, 41, 248-262.

Републичка агенција за просторно планирање. (2012). Просторни план подручја посебне намене археолошког налазишта Виминацијум. 
http://www.rapp.gov.rs/Storage/Global/Documents/2015/Viminacijum/ Plan-usvojen.pdf, Downloaded 08. June 2017.

http:/ / viminacium.org.rs/ projekti/t-pas/, Downloaded 15. June 2017.

http:/ / viminacium.org.rs/projekti/ projekat-arkwork/, Downloaded 15. June 2017. 